\title{
Role of the District Government in Empowerment of Small and Medium Enterprises in Tabanaz-Bali
}

\author{
Supartha Wayan Gede ${ }^{1}$, Saroyeni Piartrini Putu ${ }^{2}$ \\ ${ }^{1}$ Faculty of Economics and Business, Udayana University \\ ${ }^{2}$ Faculty of Economics and Business, Udayana University \\ Corresponding Author’s Email: yande.partha@gmail.com
}

\begin{abstract}
Many attempts have been made to develop Small and Medium Enterprises (SMEs). However, this research focuses on the role of district governments in empowering SMEs. This study, uses the SWOT Analysis to examine the variables that influence in empowerment of SMEs in Tabanan. The purpose of this study; Identify Strengths, Weaknesses, Opportunities and Threats and formulate a strategy for empowering SMEs in Tabanan. This research is descriptive and exploratory to find various variables that affect the performance of SMEs and is formulated as part of the SMEs empowering strategy. The sample of this study was 100 SMEs entrepreneurs spread over 10 (ten) sub-districts in Tabanan. The study results show, the Tabanan District Government must: (i) provide training to improve the capacity of SMEs in managerial and technical fields, financial management and accounting in managing their businesses; (ii) allocating more funds for the development of SMEs in Tabanan to increase their productivity; (iii) launching a trade center program to accommodate SMEs products and to market in an integrated and continuous manner, both for markets within and outside Bali; (iv) SMEs in Tabanan should improve their ability in the production process, maintain product quality and product design so that their products remain in demand by consumers and (v) SMEs should join an organization and market their products through e-commerce applications.
\end{abstract}

Keywords: empowerment of SMEs, SWOT Analysis, role of district government

\section{INTRODUCTION}

Small and Medium Enterprises (SMEs) play an important role in promoting economic growth and development (Muritala et. al. 2012). SMEs in the Indonesian National economy have an important and strategic role in sustaining economic growth. The growth and development of small and medium-sized businesses will encourage growth in employment opportunities and increase community welfare. 
Asli and Kunt (2012), stated the problems of SMEs were lack of capital, difficulties in marketing, raw materials, lack of skill in the production process, lack of managerial and financial capabilities, and a less conducive business climate. Urata (2000) shows the main problems faced by SMEs are many SMEs not yet bankable, because the financial aspects are not transparent, and the lack of managerial ability in finance.

In 2017 there were 5,003 SMEs, spread in ten sub-districts in Tabanan Regency. The SMEs consisted of 4,875 small businesses (97.44\%) and 128 medium businesses $(2.56 \%)$. The contribution of SMEs in the formation of the Gross Regional Domestic Product (GRDP) Tabanan, in 2017 was 5.9 percent (Tabanan District Office of Cooperatives and SMEs, 2018).

The problems of SMEs in Tabanan Regency are: lack of capital, limited raw materials, lack of expertise in production techniques, difficulties in product marketing, fierce business competition, lack of managerial skills, lack of financial management knowledge, and a less conducive business climate. Thus the coaching program is needed especially in empowering SMEs.

The role of government is needed in empowering SMEs. Jim Bell et. al. (2004), states the role of government and large companies is very significant in promoting SMEs. Mile (2010) states cooperation between fellow craftsmen and government support is an alternative to overcome problems in developing SMEs.

Marketing skills are needed in the development of SMEs. Athanasios (1999) states the obstacles faced by SMEs are in terms of; innovation and development of business networks (marketing). Devi and Byung (2009), stated the role of marketing (technological innovation) is needed to improve the performance of SMEs. Urata (2000), states marketing or network marketing is an obstacle in the development of SMEs.

In terms of capital, Yuri (2000) explained the empowerment of the small business sector must be done by providing affordable business financing sources. Urata (2000), Asli and Kunt (2012) and Ladislav (2012) stated business capital or capital or financial access is needed in the development of SMEs.

From the production process side, Athanasios (1999) states the problems often faced by SMEs include: the low ability of production techniques (production processes) and quality control. Urata (2000) identifies SME problems including: poor quality control, production equipment.

Related to human resources (HR), Urata (2000), Ladislav (2012), Mile (2010) and Yuri (2000), stated the quality of human resources or labor and creativity is needed in the development of SMEs.

The availability of raw materials is needed by SMEs. Urata (2000) states the problem of SMEs is quality control (raw materials) and production equipment. 
Based on those problems, a study on "The Role of Local Government in Empowering Small and Medium Enterprises (SMEs) in Tabanan Regency - Bali" has be done.

\section{Small and Medium Enterprises (SMEs), and the Government's Role}

\section{Small and Medium Enterprises (SMEs)}

Based on Law No. 20 of 2008 concerning Business, Micro, Small and Medium Enterprises (MSMEs), which is meant by: (i) Small Business is a productive economic business that stands alone which is carried out by individuals not directly or indirectly a subsidiary. Criteria for small businesses having a net worth of between Rp 50 million to Rp 500 million excluding land and buildings where businesses or sales turnover ranges from Rp 300 million to Rp 2.5 billion, (ii) Medium Business is a productive economy that stands alone conducted by individuals not directly or indirectly a subsidiary. Criteria for medium-sized businesses have a wealth of more than $\mathrm{Rp} 500$ million to $\mathrm{Rp} 10$ billion, excluding land and buildings where businesses or sales turnover ranges from $\mathrm{Rp} 2.5$ billion to Rp 50 billion.

\section{Role of the Government}

Mubyarto (2002) states empowerment is an effort to build power (community) by encouraging, motivating, and raising awareness of their potential and striving to develop. Empowerment of a people's economy must be carried out by the government in collaboration with non-governmental organizations and the banking society. Kartasasmita (1995) stated that empowerment must be carried out in three ways as follows: (a) creating a conducive climate, so that the community's economy can develop; (b) strengthen the potential of the community by preparing infrastructure both physical and social that can be accessed by the lowest strata of society; and (c) empower in the sense of protecting and defending weak communities.

SMEs is a strength in the implementation of social economy. Therefore, the existence of SMEs must be protected and empowered by the government. In Law No.20 / 2008 on MSMEs, empowerment is an effort made by the Government, Regional Government, Business Groups, and the Community in synergy to foster a business climate for SMEs so that SMEs are able to grow and develop into a strong and independent business.

\section{Strategy and Empowerment of SMEs}

Griffin and Moorhead (2014) states a strategy is a series of plans and actions needed to achieve organizational goals. Each organization strives to develop 
strategies that enable the organization to achieve its stated goals. Strategy is the art of integrating or interacting between key success factors so that synergy occurs in achieving goals. Strategy is a means to an end. The benefit of the strategy is to optimize superior resources in maximizing the achievement of performance goals. In the management concept the best way to achieve goals, objectives and performance is a strategy to empower resources effectively and efficiently.

\section{Marketing}

According to Michaelidou et. al (2011) the core of marketing is identifying and meeting human and social needs. One brief definition of marketing is "meeting needs in a profitable way". From this views, marketing management as the art and science of choosing target markets and reaching, retaining, and growing customers by creating, delivering and communicating superior customer value. They distinguish marketing management in two definitions, social definition and managerial definition. By definition social marketing is a social process where individuals and groups get what they need and want by creating, offering and freely exchanging valuable products and services with others.

\section{Capital}

According to Macchiaroli (2010) capital is the amount of money or goods used for company activities consisting of fixed capital such as factory buildings, machinery and working capital such as receivables, goods, material preparations, half goods finished and finished goods. While Gilarso (1993), states that in economics the term capital (capital, capital goods) as a factor of production refers to all facilities and infrastructure (other than human and natural gifts) produced to be used as input (input) in the production process: buildings and construction, tools and machinery, and additions to inventory.

\section{Raw material}

Raw materials are one of the most active elements in the company which are continually obtained, modified and then resold (Su-Yol, 2008). Most of the sources of companies are also often linked in the supply of raw materials that will be used in the operation of the factory company. Raw Materials are goods obtained for use in the production process. Some raw materials are obtained directly from natural sources. However, more often than not, raw materials are obtained from other companies and this is the final production of the suppliers.

\section{Production process}

According to $\mathrm{Su}-\mathrm{Yol}$ (2008) the process is defined as a way, method and technique of how the actual sources (labor, machinery, materials and funds) are changed to obtain a result. Production is an activity to create or add to the use of goods or services. The process is also interpreted as a way, method or technique of 
how the production is carried out. Production is an activity to create and add utility to goods and services. According Loh and Koh (2004) the production process is a method, method or technique to increase the use of goods and services using existing production factors.

\section{Quality of HR}

Human Resources according Kuan (2005) is a workforce or employee in an organization that has an important role in achieving success. Heather (2010) stated that human resources are people who work in an organization (also called personal labor, or employees). Macchiaroli (2010) argues the notion of the quality of human resources is the value of a person's behavior in being responsible for all his actions both in personal life as well as community and national life.

\section{Accounting}

Fauzul et. al. (2010) states, accounting is an information system that is able to measure business activities, process data into reports, and communicate the results to decision makers (managers). Where as Joshua and Peter (2010) defines accounting as an information system that produces reports to interested parties regarding economic activities and company conditions that are useful in decision making.

\section{METHODOLOGY}

\section{Population and Sample}

The population in this study was 5,003 SMEs, which consisted of 4,875 small businesses (97.44\%) and 128 medium businesses (2.56\%). A sample of 100 SME units were spread in ten sub-districts in Tabanan Regency.

\section{Data collection}

Data collection is done by 1) Observation, by observing directly on selected SMEs, 2) Structured interviews, by asking questions directly to respondents using a questionnaire.

\section{Data analysis method}

SWOT analysis is used to analyze data and a descriptive analysis is performed to describe or give an overview of the object under study through data samples or populations as they are, without conducting analysis and making conclusions that are generally accepted (Hair et. all., 2010). SWOT analysis is an excellent tool to be used in making strategic planning for SMEs (Houben et. al., 1995). 


\section{Conceptual framework}

The conceptual framework of this study can be seen in Figure 1.

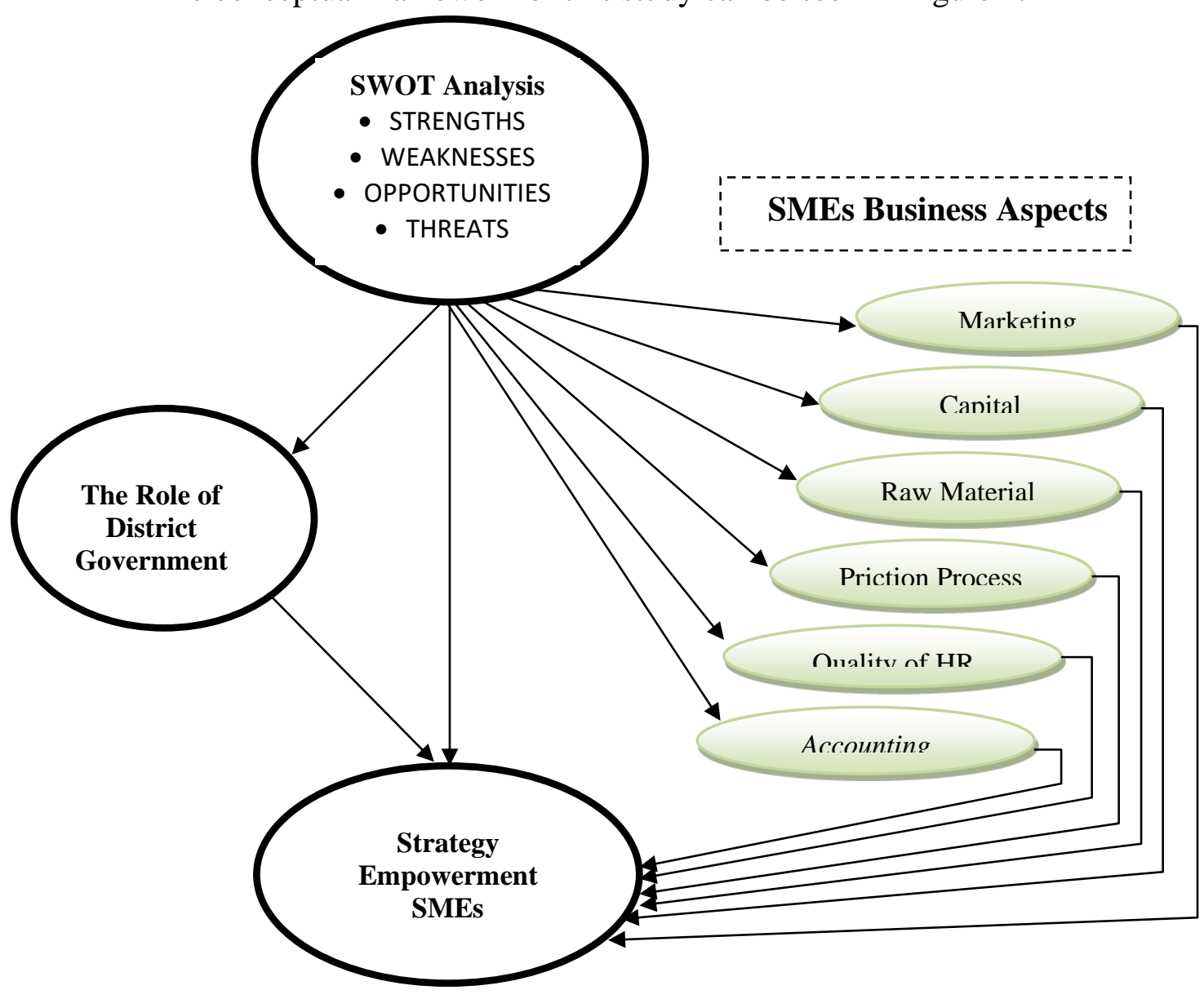

Figure 1.

Conceptual Framework

Empowerment of Small and Medium Enterprises (SMEs)

in Tabanan Regency

\section{RESULTS AND DISCUSSION}

\section{Demographic Characteristics of Respondents}

Characteristics of respondents, can be explained as follows: by sex; 67 men $(67.0 \%)$ and 33 women (33.0\%). In terms of education level; There were 33 scholars $(33.0 \%), 67$ graduates $(67.0 \%)$. In terms of age; respondents aged 35 years old were 14 people (14.0\%), respondents aged $35-45$ years were 42 people (42.0\%), respondents aged 46-55 years were 39 people (39.0\%) and respondents aged over 
55 years as many as 5 people (5.0\%). In terms of length of work; respondents who have worked less than 5 years are 25 people $(25.0 \%)$, respondents who have worked for 6-10 years are 50 people (50.0\%), respondents who have worked 11-15 years are 15 people $(15,0 \%)$, and respondents with years of work over then 15 years and over as many as 10 people $(10.0 \%)$.

\section{Identification of Internal and External Factors in SMEs in Tabanan Regency}

The internal factors (strengths and weaknesses) and external factors (opportunities and threats) owned by UKM in Tabanan Regency are as follows.

1. Strengths (Strenghts) consist of: distribution, pricing of products, access to sources of capital (Government Banks, Private Banks, BPRs, LPDs, Cooperatives and others), layout, environmentally friendly, individual integrity, individual commitment, preparation of financial statements / financial transactions and carrying out periodic calculations between costs (effort) and results (achievements).

2. Weakness consists of: product design, packaging (packaging), Promotion, speed of capital fulfillment, total capital fulfillment / needs, equipment / machinery / technology, Standard Operating Procedure (SOP), managerial competence, technical competence, organizing accounting to measure business activities and separate business finance from personal finance

3. Opportunities consist of: the role of government in; facilitate the marketing of products, facilitate access to capital, facilitate the development and skills of human resources, facilitate training in administration and accounting and source of raw materials, quality of raw materials

4. Threats (Threats) consist of: not facilitating the supply of raw materials, not facilitating in the ease of obtaining production equipment (production process), not guaranteed quantity / quantity of raw materials and not guaranteed continuity of raw materials.

\section{Internal Factor Analysis Summary (IFAS Matriks)}

The results of calculations from the IFAS matrix can be seen as in Table 1

Table 1.

Internal Factor Analysis Summary (IFAS Matriks)

\begin{tabular}{|c|l|l|l|l|}
\hline NO. & INTERNAL STRATEGIC FACTORS & Wight & Rating & $\begin{array}{c}\text { Skor } \\
\text { Wight } \mathbf{x} \text { Rating }\end{array}$ \\
\hline I. & Strenghts & & & \\
\hline A. & Marketing Variable & & & \\
\hline
\end{tabular}




\begin{tabular}{|c|c|c|c|c|}
\hline 1 & Distribution & 5 & 3,00 & 0,149 \\
\hline 2 & Product pricing & 5 & 3,10 & 0,165 \\
\hline B. & Capital Variable & & & \\
\hline 3 & $\begin{array}{l}\text { Access to capital sources (Government } \\
\text { Banks, Private Banks, BPRs, LPDs, } \\
\text { Cooperatives and others }\end{array}$ & 6 & 2,82 & 0,158 \\
\hline C. & Production Process Variables & & & \\
\hline 4 & Layout & 5 & 3,18 & 0,143 \\
\hline 5 & Environmentally friendly & 5 & 3,18 & 0,159 \\
\hline D. & HR Quality Variable & & & \\
\hline 6 & Individual integrity & 6 & 2,77 & 0,156 \\
\hline 7 & Individual commitment & 5 & 3,16 & 0,173 \\
\hline E. & Accounting Variables & & & \\
\hline 8 & $\begin{array}{l}\text { Prepare financial reports / financial } \\
\text { transactions }\end{array}$ & 5 & 2,76 & 0,127 \\
\hline 9 & $\begin{array}{l}\text { Carry out a periodic calculation between } \\
\text { costs (effort) and results (achievements) }\end{array}$ & 5 & 3,18 & 0,169 \\
\hline II. & Weakness & & & \\
\hline A. & Marketing Variable & & & \\
\hline 1 & Product Design & 5 & 3,10 & 0,163 \\
\hline 2 & Packaging (packaging) & 5 & 2,74 & 0,140 \\
\hline 3 & Promotion & 5 & 2,78 & 0,134 \\
\hline B. & Capital Variable & & & \\
\hline 4 & Speed of capital fulfillment & 5 & 2,70 & 0,135 \\
\hline 5 & Total capital needs / fulfillment & 5 & 2,77 & 0,127 \\
\hline C. & Production Process Variables & & & \\
\hline 6 & Equipment / machinery / technology & 4 & 2,70 & 0,111 \\
\hline 7 & Standard Operating Procedure (SOP) & 5 & 2,77 & 0,143 \\
\hline D. & HR Quality Variable & & & \\
\hline 8 & Managerial competence & 5 & 3,18 & 0,175 \\
\hline 9 & Technical competence & 5 & 2,68 & 0,126 \\
\hline
\end{tabular}




\begin{tabular}{|c|l|c|c|c|} 
& & & & \\
\hline E. & Accounting Variables & & & \\
\hline 10 & $\begin{array}{l}\text { Carrying out accounting to measure } \\
\text { business activities }\end{array}$ & 5 & 3,18 & 0,150 \\
\hline 11 & $\begin{array}{l}\text { Separate business / usha finance with } \\
\text { personal finance }\end{array}$ & 5 & 2,70 & 0,124 \\
\hline & \multicolumn{1}{|c|}{ TOTAL } & $\mathbf{1 0 0}$ & & $\mathbf{2 , 9 2 8}$ \\
\hline
\end{tabular}

Source: Research Results

\section{External Factor Analysis Summary (EFAS Matriks)}

The results of calculations from the EFAS matrix can be seen as in Table 2

Table 2

External Factor Analisys Summary Matriks (EFAS Matriks)

\begin{tabular}{|c|l|c|c|c|}
\hline NO. & EXTERNAL STRATEGIC FACTORS & Wight & Rating & $\begin{array}{c}\text { Skor } \\
\text { Wight x Rating } \\
\mathbf{1 0 0}\end{array}$ \\
\hline I. & Opportunities & & & \\
\hline A. & Government Role Variable & & & \\
\hline 1 & Facilitating product marketing & 12 & 3,61 & 0,440 \\
\hline 2 & Facilitating access to capital & 11 & 3,17 & 0,361 \\
\hline 3 & Facilitating HR development and skills & 11 & 3,17 & 0,364 \\
\hline 4 & $\begin{array}{l}\text { Facilitating training in administration and } \\
\text { accounting }\end{array}$ & 10 & 3,20 & 0,319 \\
\hline B. & Raw Material Variables & & & \\
\hline 5 & Ingredients source & 10 & 2,86 & 0,291 \\
\hline 6 & Quality of raw materials & 10 & 2,85 & 0,294 \\
\hline II. & Threats & & & \\
\hline A. & Government Role Variable & & & \\
\hline 1 & Facilitating the supply of raw materials & 9 & 2,43 & 0,218 \\
\hline 2 & $\begin{array}{l}\text { Facilitating the ease of obtaining } \\
\text { production equipment }\end{array}$ & 9 & 2,43 & 0,209 \\
\hline B. & Raw Material Variables & & & \\
\hline 3 & Quantity / amount of raw material & 9 & 2,01 & 0,176 \\
\hline 4 & Continuity of raw materials & $\mathbf{1 0 0}$ & & $\mathbf{2 , 8 5 5}$ \\
\hline & & & & \\
\hline Sourat & Resear Resuls & & \\
\hline
\end{tabular}

Source: Research Results 


\section{Internal - External Matrix}

Based on the IFAS - EFAS Matrix, the total IFAS score is 2.928 and the EFAS score is 2.855. The explanation can be seen as in the Internal - External Matrix as in Figure 2.

\section{Figure 2}

\section{Internal - External Matrix}

Total Internal Strategy Score

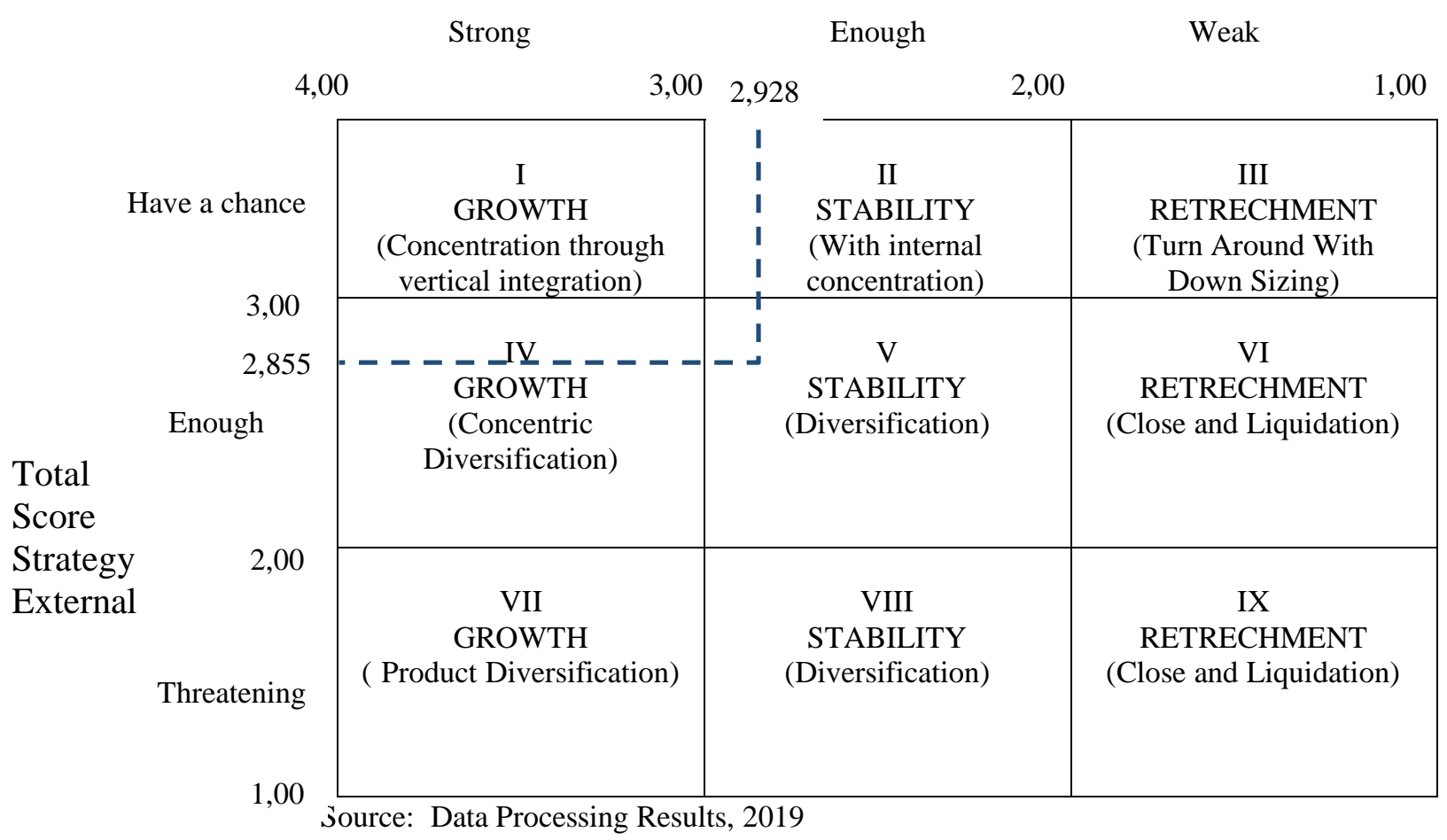

\section{Discussion}

\section{SWOT Matrix}

Based on Figure 1 (Internal - External Matrix) it can be stated the position of SMEs in Tabanan Regency has a position on Stability with diversification of business concentration. This is indicated by conditions in the marketing (distribution and determination of cost of goods are strengths). In the capital, access to sources of capital (government banks, private banks, rural banks, LPDs, cooperatives and other financial institutions) is a strength. In the production, building layout and environmentally friendly production processes are strengths. In the quality human resources, individual integrity and individual commitment to advance SMEs are strengths. In the accounting, preparing financial reports and carrying out calculations of business costs and operating results carried out periodically is a strength. 
On the other hand, marketing (product design, product packaging and product promotion) is a weakness. In the capital, the speed of capital fulfillment, as well as the amount of capital can be met, is a weakness. In the production processes, equipment / machinery / technology as well as standard operating procedures (SOP) are weaknesses. In the HR quality, managerial competence and technical competence are weaknesses. In the accounting, conducting accounting to measure business activities and to separate business / business finance from personal finance is a weakness.

In terms of opportunities, the role of government in facilitating product marketing, facilitating access to capital, facilitating managerial development and HR skills, facilitating training in administration and accounting is an opportunity for SMEs. In the raw materials, the source of raw materials and the quality of raw materials are opportunities for SMEs in developing business.

In terms of threats, the role of the government in facilitating raw materials, facilitating the ease of obtaining production equipment is a threat. In the raw materials, the quantity or quantity of raw materials and the continuity of raw materials are a threat.

\section{Development Strategy for SMEs in Tabanan Regency}

In general, the position of SMEs in Tabanan Regency is in cell V, namely Stability with Diversification in the sense of using the internal strength (strength) of SMEs by taking advantage of opportunities. On the other hand, the internal weaknesses (Weakness) of SMEs must be corrected, increased by the government and by the SMEs themselves and the threats (Threats) faced by SMEs must be overcome by the government and by the SMEs themselves.

Development Strategy for SMEs in Tabanan Regency can be seen in Table 3.

Table 3

Strategy Matrix for SMEs Empowerment in Tabanan Regency

\begin{tabular}{|ll|l|}
\hline \multicolumn{2}{|c|}{ STRATEGY (SO) } & \multicolumn{1}{|c|}{ STRATEGY (WO) } \\
\hline $\begin{array}{l}\text { Utilize the facilities provided by the } \\
\text { government to increase the distribution of } \\
\text { goods that are easier for consumers }\end{array}$ & $\begin{array}{l}\text { 1 } \begin{array}{l}\text { Improve product design and packaging } \\
\text { processes in product marketing by } \\
\text { utilizing the government's role in product } \\
\text { marketing. }\end{array} \\
2 \text { Utilize access to capital by using facilities } \\
\text { provided by the government }\end{array}$ & $\begin{array}{l}\text { Utilizing the role of the government in } \\
\text { increasing capital to accelerate and } \\
\text { increase the amount of business capital }\end{array}$ \\
$\begin{array}{l}\text { Improving the integrity and commitment of } \\
\text { SME managers by utilizing opportunities } \\
\text { provided for the development and } \\
\text { improvement of HR management skills }\end{array}$ & $\begin{array}{l}\text { Utilize government facilities in the } \\
\text { development and improvement of HR } \\
\text { skills to improve SME managerial and } \\
\text { technical competence }\end{array}$ \\
\hline \multicolumn{2}{|l}{} \\
\hline
\end{tabular}




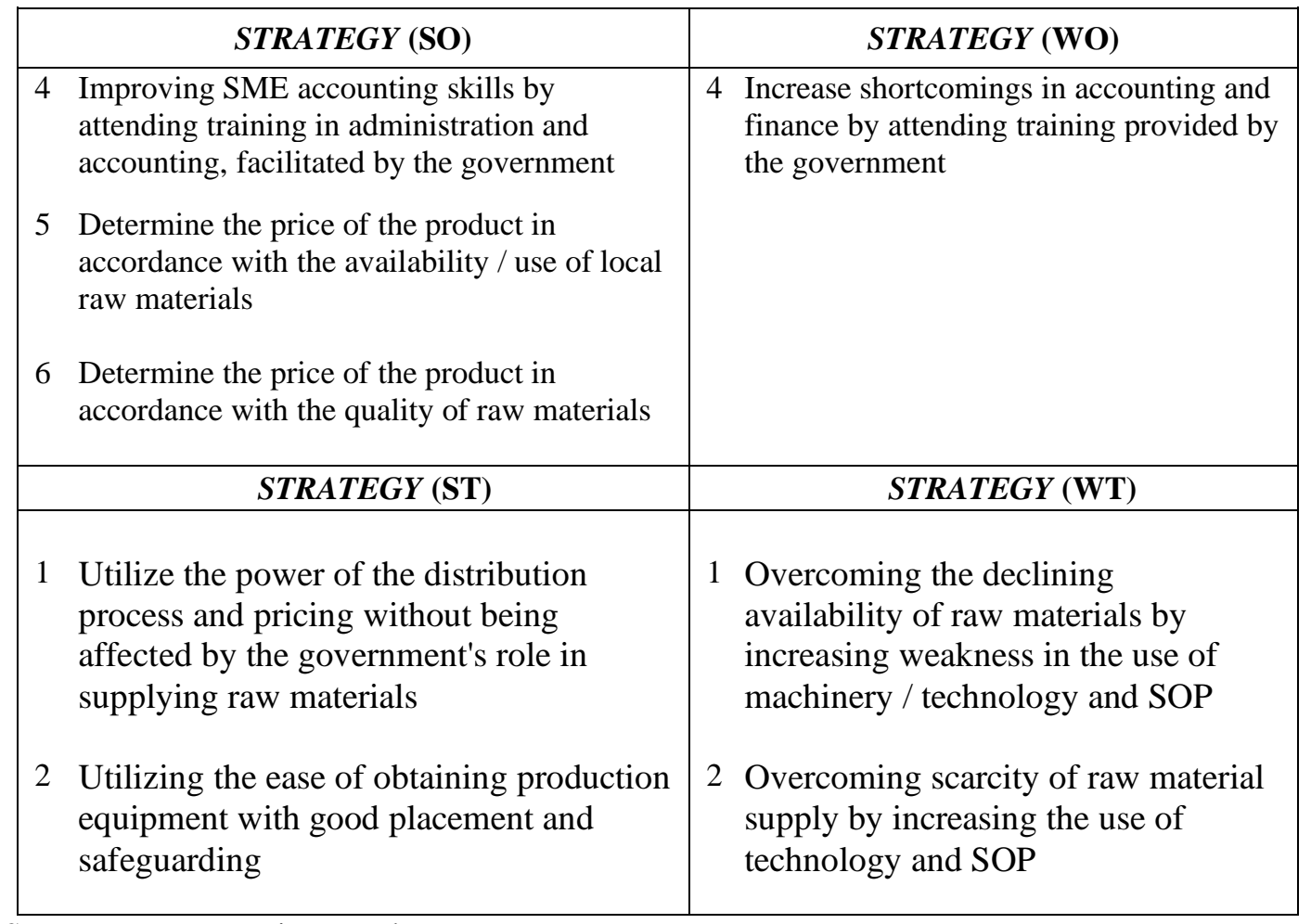

Source: Data Processing Results

\section{CONCLUSIONS AND SUGGESTIONS}

\section{Conclusions}

Based on an analysis of the environment of Tabanan Regency SMEs, both internal and external environments, the following conclusions are obtained:

1) Internal factors that are the main strength of SMEs in Tabanan Regency are; distribution, product pricing, access to capital resources, layout, environmentally friendly, individual integrity, individual commitment, compiling financial reports / financial transactions, carrying out periodic calculations between costs (business) and results (achievements); While the main weaknesses of SMEs in Tabanan Regency are: product design, packaging, promotion, speed of capital fulfillment, total fulfillment / capital requirements, equipment / machinery / technology, standard operating procedures (SOP), managerial competence and technical competence.

2) External factors which are the main opportunities for SMEs in Tabanan Regency are: the government facilitates the marketing of products, the government facilitates access to capital, the government facilitates the development and skills of human resources, the government facilitates training in administration and accounting, the availability of raw material sources, the quality of materials standard; whereas the main threats to SMEs in Tabanan Regency are: the 
government facilitates the supply of raw materials, the government facilitates the ease of obtaining production equipment (production processes), quantity / quantity of raw materials, continuity of raw materials.

3) Based on the SWOT analysis, obtained alternative strategies for developing SMEs in Tabanan Regency, namely SO Strategy, WO Strategy, ST Strategy, WT Strategy, as follows:

a. SO Strategy: (1) Utilizing facilities provided by the government to improve the distribution of goods that are easier to consumers, (2) Utilizing access to capital by using facilities provided by the government, (3) Improving the integrity and commitment of SMEs managers by utilizing opportunities provided for the development and improvement of managerial HR skills, (4) Improving SMEs accounting skills by attending training in administration and accounting facilitated by the government, (5) Determining product prices in accordance with the availability / use of local raw materials and (6) Determining prices for products in accordance with the quality of raw materials.

b) WO Strategy: (1) Improve the product design and packaging process in product marketing by utilizing the government's role in product marketing. (2) Utilizing the role of government in raising capital to accelerate and increasing the number of business capital, (3) Utilizing government facilities in developing and enhancing HR skills to improve managerial and technical competence of SMEs and (4) Increasing shortcomings in accounting and finance by attending training provided by the government.

c) ST Strategy; (1) Utilizing the power of the distribution process and pricing without being affected by the role of the government in the supply of raw materials and (2) Utilizing the ease of obtaining production equipment with a good and safe placement.

d) WT Strategy; (1) Overcoming the declining availability of raw materials by increasing weaknesses in the use of machinery / technology and SOP and (2) Overcoming the scarcity of raw material supply by increasing the use of technology and SOP. 


\section{Suggestions}

Based on the conclusions above, the suggestions are:

1) The Tabanan District Government should provide training for SMEs HR in increasing the capacity of SMEs in managerial and technical aspect, financial management and accounting in the management of SMEs.

2) The Tabanan District Government should allocate more funds for the development of SMEs in Tabanan Regency in order to increase their productivity.

3) The Tabanan District Government should launching a trade center program to accommodate SMEs products to be able to be marketed in an integrated and continuous manner, both for markets within Bali and outside Bali.

4) SMEs in Tabanan Regency should join and market their SMEs products in one e-commerce application and of course with government support so that Tabanan SMEs products can be marketed easily.

5) SMEs in Tabanan Regency should improve their ability in the production process, maintain product quality and product design so that their products remain in demand by consumers.

\section{REFERENCES}

Asli Demirgüç dan Kunt Leora Klapper. 2012. Financial Inclusion in Africa an Overview. Policy Research Working Paper. The World Bank Development Research Group Finance and Private Sector Development Team. June 2012.

Athanasios Hadjimanolis. 1999. Barriers to innovation for SMEs in a small less developed country (Cyprus). Technovation 19 (1999) 561-570. www.elsevier.com/locate/technovation.

Devi R. Gnyawali and Byung-Jin. 2009. Co-opetition and Technological Innovation in Small and Medium-Sized Enterprises:A Multilevel Conceptual Model. Journal of Small Business Management 2009 47(3), pp. 308-330.

Fauzul Mafasiya Fairoz. Takenouchi Hirobumi and Yukiko Tanaka. 2010. Entrepreneurial Orientation and Business Performance of Small and Medium Scale Enterprises of Hambantota District Sri Lanka. Asian Social Science. Vol. 6, No. 3. March, 2010.

Griffin Ricy W. and Moorhead Gregory. 2014. Organizational Behavior. Managing People and Organizations, $11^{\text {th }}$ Edition. South Western, Cengage Learning. United States. 
Hair, J.F., Black, W.C., Babin, B.J., dan Anderson, R.E. 2010. Multivariate Data Analysis, $7^{\text {th }}$ edition. NJ: Pearson Prentice Hall.

Heather Banham. 2010. External Environtmental Analiysis For Small and Medium Enterprises.

Houben G., K. Lenie, and K. Vanhoof. 1999. A knowledge-based SWOT-analysis system as an instrument for strategic planning in small and medium sized enterprises. Decision Support Systems 26 (1999) 125-135.

Jim Bell, Dave Crick and Stephen Young. 2004. Small Firm Internationalization and Business Strategy An Exploratory Study of 'Knowledge-intensive' and 'Traditional' Manufacturing Firms in the UK. International Small Business Journal Copyright (C) 2004. SAGE Publications (London).

Joshua Abor and Peter Quartey. 2010. Issues in SME Development in Ghana and South Africa. International Research Journal of Finance and Economics. ISSN 1450-2887 Issue 39 (2010).

Kartasasmita, G. 1995. Pemberdayaan Masyarakat : Konsep Pembangunan yang Berakar pada Masyarakat. Bandung. ITB

Kuan Yew Wong. 2005. Critical success factors for implementing knowledge management in small and medium enterprises. Industrial Management \& Data Systems Vol. 105 No. 3, 2005. pp. 261-279.

Ladislav Mura and Ján Buleca. 2012. Evaluation of Financing Possibilities of Small and Medium Industrial Enterprises. Procedia Economics and Finance 3 ( 2012 ) $217-222$.

Loh T. C. and S. C. L. Koh. 2004. Critical elements for a successful enterprise resource planning implementation in small- and medium-sized enterprises. International Journal of Production Research. september 2004, vol. 42, no. 17, 3433-3455. ISSN 0020-7543 print/ISSN 1366-588X online.

Macchiaroli, Fera. 2010. Appraisal of a New Risk Assessment Model for Small and Medium Sized Enterprises.

Michaelidou, N., Siamagka, N.T. and Christodoulides. 2011. Usage, Barriers and Measurement of Social Media Marketing: An Exploratory Investigation of Small and Medium B2b Brands. Industrial Marketing Management, 40(7), pp.1153-1159.

Milé Terziovski. 2010. Innovation Practice And Its Performance Implications In Small To Medium Enterprises (Smes) In The Manufacturing Sector: A Resource-Based View. Strategic Management Journal. 31 (8): Pp. 892-902, Which Has Been Published In Final Form At Http://Doi.Org/10.1002/Smj.841.

Mubyarto. 2002. Membangkitkan Ekonomi Kerakyatan Melalui Gerakan Koperasi: Peran Perguruan tinggi”. Artikel Dalam Jurnal Ekonomi Rakyat, Thn I, No 6, tersedia di http;//www.ekonomikerakyatan.org.

Muritala Taiwo, Awolaja Ayodeji and Bako Yusuf. 2012. Impact of Small and Medium Enterprises on Economic Growth and Development. American Journal of Business and Management Vol. 1, No. 1, 2012, 18-22. 
Su-Yol Lee. 2008. Drivers for the participation of small and medium-sized suppliers in green supply chain initiatives. Supply Chain Management: An International Journal. Volume $13 \cdot$ Number $3 \cdot 2008 \cdot 185-198$.

Undang-Undang No. 20 Tahun 2008 tentang Usaha, Mikro, Kecil dan Menengah (UMKM).

Urata Shujiro. 2000. Policy Recommendatins: Outline of ten tattive Policy Recomendation for SME Promotion in Indonesia, Publikasi JICA 17 Mei 2007

Yuri Sato. 2000. How Did The Crisis Affect Small And Medium-Sized Enterprises?

From A Field Study Of The Metalworking Industry In Java. The Developing Economies, Xxxviii-4 (December 2000): 572-95. 